\title{
Rapid identification of bacterial antigen in blood cultures and cerebrospinal fluid
}

\author{
R GRAHAM WILliaMS, C A HART Department of Microbiology, Royal Liverpool Children's \\ Hospital, Alder Hey, Liverpool
}

SUMMARY The ability of antibody coated latex particle suspensions to aid the diagnosis of septicaemia and meningitis in children was assessed in 272 blood culture sets and 85 cerebrospinal fluid specimens. This was also assessed in cases caused by Neisseria meningitidis group B infection.

The method was $100 \%$ sensitive and $99 \%$ specific, with good predictive values (range $63 \%$ to $100 \%$ ) and provided valuable support to the routine bacteriological examination of blood culture and cerebrospinal fluid.

The production of a clinically useful bacteriological report depends on the time it takes for the organism to grow under test and may result in a delay of 18 hours or longer. Even after such a delay, cultures may fail to yield growth because of previous antimicrobial treatment. Rapid reporting is important when the patient has septicaemia or meningitis to facilitate prompt and appropriate antimicrobial treatment.

Several methods exist for the rapid detection of bacterial growth in blood cultures-for example, radiometric, ${ }^{1-3}$ impediometric, ${ }^{34}$ or infrared $^{56}$ techniques. If these are used in conjunction with a Gram stained film any of these techniques will quickly confirm the presence of bacteria and may give some indication of the family or genus of the infecting organism. Clinical guidance could be made more accurate if it were possible to identify the bacterium without awaiting growth. This can be achieved using immunological methods based on antigen detection, such as counterimmunoelectrophoresis (CIE), ${ }^{7}$ coagglutination $(\mathrm{COA})^{8}$ using staphylococci bearing protein $A$, and latex particle agglutination (LPA). The lack of an effective reagent for the detection of Neisseria meningitidis group B has previously been an important omission in all of the above methods.

Increasing use of CIE and COA has indicated various problems, including low sensitivity, lack of specificity, and cross reactions (personal observation). ${ }^{39-12}$ We evaluated a latex particle agglutination system which uses latex particles coated with monovalent or polyvalent antibodies to detect bacterial antigens in blood cultures and cerebrospinal fluid from children.

Accepted for publication 26 January 1988

\section{Patients and methods}

Samples were received from children admitted to the Royal Liverpool Children's Hospital (comprising Alder Hey and Myrtle Street units) with suspected bacterial septicaemia or meningitis, and from severely ill children with fever of unknown origin between February 1984 and May 1986.

Suspensions of latex particles coated respectively with antibodies to Streptococcus pneumoniae, Haemophilus influenzae (Pitman type b), and Neisseria meningitidis (groups A, C, Y, W135) were obtained from Wellcome Diagnostics (Beckenham, Kent). Later in the study latex particles coated with a monoclonal antibody to $N$ meningitidis group B were also made available to us. Suspensions of known antigen were used as positive controls and uncoated latex particles were used as a negative control.

Blood cultures were collected in two bottles of brain heart infusion, one incorporating para-aminobenzoic acid (PABA) and sodium polyanethanol sulphate, and the other PABA, vitamin $\mathrm{K}$, and haemin (Gibco, Paisley). A $2 \mathrm{ml}$ aliquot was aseptically removed from each bottle after 18 hours of incubation and centrifuged at $1000 \times g$ for 10 minutes. The supernatant was subsequently used for tests.

Following routine bacteriological examination of cerebrospinal fluid (cell count, Gram stain, and culture) the supernatant fluid from centrifuged specimens was tested.

The antibody coated and control latex suspensions $(25 \mu$ l) were pipetted on to individual areas of a black tile. Blood culture or cerebrospinal fluid supernatant $(40 \mu \mathrm{l})$ was added to each suspension and mixed with separate wooden sticks. The tile was then rocked 
gently for three minutes, while looking for macroscopic agglutination. Agglutination was compared with that obtained with the negative control and was assessed as negative, positive, or weakly positive. All supernatant samples showing agglutination were then heated in a boiling water bath for five minutes, centrifuged, and retested as above. Only those which still showed agglutination were recorded as positive.

Two sources of false positive results were postulated: the presence of protein $A$ and degeneration of blood cells. To investigate these possibilities two blood culture sets (different batch numbers) were inoculated with the Cowan strain of Staphylococcus aureus and tested after 18 hours of incubation as above. In addition, protein A (Sigma UK) was mixed with the latex suspensions and examined for agglutination after rocking for three minutes. A series of 26 latex particle agglutination negative blood culture sets was stored at room temperature and retested seven and 21 days later.

The performance characteristics of the four antibody coated latex suspensions were calculated according to the methods of Galen and Gambino. ${ }^{13}$

\section{Results}

Two hundred and seventy two blood culture sets and 85 cerebrospinal fluid specimens from severely ill children were examined by latex particle agglutination. One hundred and forty eight $(54 \%)$ and 22 $(26 \%)$, respectively, were found to contain bacteria by routine culture-a total of 170 . Of these, 64 contained bacteria for which appropriate latex suspensions were available (table 1). Sixty three $(98 \%)$ gave an appropriate latex particle agglutination only and one $(2 \%)$ agglutinated with both monovalent and polyvalent $N$ meningitidis latex suspensions ( $N$ menin-

Table 1 Detection of bacteria in blood culture and cerebrospinal fluid* by LPA

\begin{tabular}{|c|c|c|c|c|}
\hline Isolate & $\begin{array}{l}\text { No of } \\
\text { specimens } \\
\text { examined }\end{array}$ & $\begin{array}{l}\text { No positive } \\
\text { with } \\
\text { appropriate } \\
\text { latex } \\
\text { suspension }\end{array}$ & $\begin{array}{l}\text { No positive } \\
\text { with } \\
\text { inappro- } \\
\text { priate latex } \\
\text { suspension }\end{array}$ & $\begin{array}{l}\text { No negative } \\
\text { with } \\
\text { all } \\
\text { latex } \\
\text { suspension }\end{array}$ \\
\hline $\begin{array}{l}N \text { meningitidis } \\
\text { group B }\end{array}$ & $14(8)$ & $13(7)$ & $1(1)$ & $0(0)$ \\
\hline $\begin{array}{l}\text { groups A, C, Y, } \\
\text { W135 } \\
\text { H influenzae }\end{array}$ & $5(3)$ & $5(3)$ & $0(0)$ & $0(0)$ \\
\hline type b & $17(2)$ & $17(2)$ & $0(0)$ & $0(0)$ \\
\hline $\begin{array}{l}\text { Streptococcus } \\
\text { pneumoniae } \\
\text { "Other" } \\
\text { Nil } \\
\text { Total }\end{array}$ & $\begin{array}{l}28(0) \\
106(9) \\
187(63) \\
357(85)\end{array}$ & $\begin{array}{c}28(0) \\
0(0) \\
0(0) \\
63(12)\end{array}$ & $\begin{array}{r}0(0) \\
10(0) \\
0(0) \\
11(1)\end{array}$ & $\begin{array}{c}0(0) \\
96(9) \\
187(63) \\
283(72)\end{array}$ \\
\hline
\end{tabular}

gitidis group B15 was grown). There were no false negative results.

One hundred and six culture positive specimens contained "other" isolates for which antibody coated latex suspensions were not available (table 2): $10(9 \%)$ gave false positive results. Two of these were blood cultures growing Escherichia coli $\mathrm{K} 1$ which agglutinated only with $N$ meningitidis group B latex suspension. As $E$ coli $\mathrm{K} 1$ and $N$ meningitidis group B share a common antigen these two specimens should be considered as having given true positive results. One was a blood culture growing Klebsiella oxytoca, which gave a weak though consistent agglutination with $\boldsymbol{H}$ influenzae type b latex. Seven were blood cultures growing $S$ aureus either in pure growth or as part of a mixture. There were no false positive results among the cerebrospinal fluid specimens.

Table 2 "Other" isolates for which appropriate antibody coated latex suspension was not available

\begin{tabular}{lc}
\hline Isolate & No of cases \\
\hline Escherichia coli & 8 \\
Klebsiella spp & 8 \\
Hafnia sp & 1 \\
Serratia sp & 1 \\
Salmonella indiana & 1 \\
Salmonella typhi & 2 \\
Pseudomonas aeruginosa & 2 \\
Acinetobacter spp & 2 \\
Candida albicans & 1 \\
Bacteroides fragilis & 1 \\
Viridans streptococci & 11 \\
Streptococcus pyogenes & 1 \\
Streptococcus agalactiae & 2 \\
Streptococcus faecalis & 1 \\
Staphylococcus aureus & 16 \\
Staphylococcus epidermidis & 34 \\
Corynebacterium sp & 1 \\
Propionibacterium acnes & 3 \\
Bacillus sp & 2 \\
Saureus + S epidermidis & 5 \\
Sepidermidis + Serratia sp & 1 \\
Saureus + S faecalis & 2 \\
Total & 106 \\
\hline
\end{tabular}

Table 3 Percentage performance characteristics of LPA test for $N$ meningitidis group $B, N$ meningitidis groups $A, C$, $Y, W 135, H$ influenzae type $b$, and $S$ pneumoniae (polyvalent)

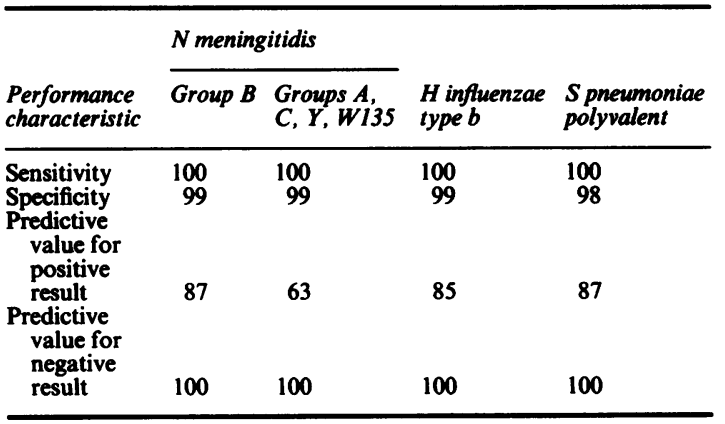


The blood culture sets inoculated with the Cowan strain of $S$ aureus all give false positive reactions and some were stable to boiling. The protein A suspension behaved similarly.

The series of 26 blood culture sets stored at room temperature after initial testing remained negative when retested in the same way at seven days. When retested at 21 days six agglutinated with all antibody coated and control latex particles but became negative after boiling.

Table 3 shows the performance characteristics of the latex particle agglutination test for four antibody coated latex particle suspensions.

\section{Discussion}

The results indicate that the latex particle agglutination technique is sensitive and specific (with high positive and negative predictive values) for $S$ pneumoniae, $H$ influenzae type b, $N$ meningitidis groups, $\mathrm{A}$, $\mathrm{C}, \mathrm{Y}, \mathrm{W} 135$, and $N$ meningitidis group $\mathrm{B} / E$ coli $\mathrm{K} 1$ ("community" acquired oropharyngeal flora). Moreover, the technique is cheap, simple to perform, and rapid to carry out. The main problems occur with $S$ aureus, which accounts for $70 \%$ of the false positive results from blood cultures. A Gram stain was found to be useful under these conditions. Protein A, which is carried by some $S$ aureus strains, is an Fc receptor which may bind to Fc components exposed on the surface of antibody coated latex particles. This was not a major disadvantage in our hands.

Human cells have been shown to share epitopes with bacteria, especially $N$ meningitidis group $B .^{14}$ It is therefore possible that false reactions may occur with methods based on antigen detection, including latex particle agglutination, particularly following the breakdown of blood cells ${ }^{10}$ during the prolonged incubation or storage of clinical specimens. We found such false reactions to be rare (none of 26 at seven days and six of 26 at 21 days) and they became negative after the specimen had been heated in a boiling water bath for five minutes.

Bacteria causing meningitis generally belong to the "community" acquired oropharyngeal flora. The positive predictive values for these organisms ranged from $63 \%$ to $87 \%$ and would be higher if a Gram stain was used. The predictive values for negative resultsthat is, sterile or negative for "community" bacteriawas $100 \%$. An important group of bacteria for which antibody coated latex particles are not available includes Enterobacteriaceae/Pseudomonadaceae/Acinetobacter sp ("hospital" acquired flora). While this group is associated with infections such as septicaemia, it is rarely responsible for acute meningitis after the neonatal period. Rather, it is associated with chronic disease-for example, colonisation of shunts used to drain cerebrospinal fluid in children with hydrocephaly.

Cross reactions between $N$ meningitidis and $E$ coli occurred in two cases. This represents a major limitation of the latex particle agglutination test when used to guide antimicrobial treatment: $N$ meningitidis is sensitive to penicillin G, $E$ coli is not; a Gram stain would readily resolve this difficulty.

Based on our experience, antibody coated latex particle agglutination provides valuable support to the routine bacteriological examination of blood culture and cerebrospinal fluid in paediatric meningitis and septicaemia.

We are much indebted to Dr H K F van Saene for his advice and help in the preparation of this article, to $\mathrm{Dr}$ $\mathrm{P}$ Shears and $\mathrm{Mr} \mathrm{D}$ White for their constructive criticism. Wellcome Diagnostics generously supplied all latex suspensions.

\section{References}

1 Deland FH, Wagner HN. Early detection of bacterial growth with carbon 14 labelled glucose. J Radiol 1969;92:154-5.

2 Deland FH, Wagner HN Jr. Automated radiometric detection of bacterial growth in blood cultures. J Lab Clin Med 1970;75: 529-34.

3 Gould JC, Duerden BI. Blood culture-current state and future prospects. J Clin Pathol 1983;36:963-77.

4 Buckland A, Kessock-Philips S, Bascomb S. Early detection of bacterial growth in blood culture by impedance monitoring with Bactometer model 32. J Clin Pathol 1983;36:823-8.

5 Corkhill JE, Rimmer K. Microbiological comparison of a new infra-red blood culture system (Bactec NR660) and a radiometric system (Bactec 460). Med Lab Sci 1987;44:150-9.

6 King A. Bone G, Philips I. Comparison of radiometric and gas capture systems for blood cultures. J Clin Pathol 1986;39:661-5.

7 Moody GJ. Methodology and application of counter current immunoelectrophoresis in microbiology. Laboratory Practice 1976;25:575-80.

8 Drow DL, Welch DF, Hensel D, Eisenach K, Long E, Slifkin M. Evaluation of the Phadebact CSF test for detection of the four most common causes of bacterial meningitis. J Clin Microbiol 1983:18:1358-61

9 Jones V, Roach S, Hart CA. Detection of bacterial antigens in cerebrospinal fluid. J Clin Pathol 1983:36:1321.

10 Thirumoorthi MC, Dajani AS. Comparison of staphylococcal coagglutination, latex agglutination and counterimmunoelectrophoresis for bacterial antigen detection. J Clin Microbiol 1979;9:28-32.

11 Fung JC, Wicher K. Minimum number of bacteria needed for antigen detection by counterimmunoelectrophoresis: in vivo and in vitro studies. J Clin Microbiol 1981:13:681-7.

12 Olcen P. Serological methods for rapid diagnosis of Haemophilus influenzae and Streptococcus pneumoniae in cerebrospinal fluid: a comparison of coagglutination, immunofluorescence and immunoelectroosmophoresis. Scand $J$ Infect Dis 1978;10:283-9.

13 Galen RS, Gambino SR. Beyond normality: the predictive value and efficiency of medical diagnoses. London: John Wiley \& Sons, 1976.

14 Schaver R, Chemistry, metabolism and biological functions of sialic acids. Adv Carbohydrate Chem Biochem 1981;40: 131-234.

Requests for reprints to: Dr R Graham Williams, Department of Microbiology, Royal Liverpool Children's Hospital, Alder Hey, Eaton Road, Liverpool L12 2AP, England. 